\title{
BIBLIOGRAFI SEJARAH KESEHATAN PADA MASA PEMERINTAHAN HINDIA BELANDA
}

\author{
Mumuh Muhsin Z. \\ Program Studi Ilmu Sejarah, Fakultas Ilmu Budaya, Universitas Padjadjaran \\ mumuhmz@unpad.ac.id
}

\begin{abstract}
History of health recently began to receive attention in Indonesia. One of the ways to trace them is through bibliographic study. Publications issued in the past, particularly in the colonial period, whether it be books, journals, magazines, newspapers can become an access to know and reconstruct the history of health in Nusantara. The purpose of this study is to inventory and identify a number of publications that appeared in the past by first described its historical context. The method used in this study is the historical method. The conclusion showed that the availability of bibliographic resources on the history of health in Indonesia is quite a lot that can be used to reconstruct the Indonesian health conditions in the colonial period. Knowledge of medical history is very useful to see the change, continuity, parallelism, and comparison of health problems in various places and at different periods.
\end{abstract}

Key words: bibliography, medical history, the Netherlands-Indie

\section{PENDAHULUAN}

Secara dialektis, dunia kedokteran yang berkembang sekarang merupakan akumulasi-sintesis dari perjalanan sejarah yang cukup panjang. Bagi yang berminat mengkaji ilmu kedokteran secara diakronis akan diperoleh gambaran mengenai berbagai hal; misalnya, jenis penyakit yang tumbuh dan berkembang pada periode-periode tertentu, obat dan

\begin{abstract}
ABSTRAK
Sejarah kesehatan belakangan ini mulai mendapat perhatian di Indonesia. Untuk menelusurinya di antaranya adalah melalui pengkajian bibliografis. Publikasi-publikasi yang diterbitkan pada masa lalu, khususnya masa kolonial, baik berupa buku, jurnal, majalah, surat kabar bisa menjadi akses untuk mengetahui dan merekonstruksi masa lalu kesehatan di Nusantara. Tujuan penelitian ini adalah menginventarisasi dan mengidentifikasi sejumlah publikasi yang terbit pada lalu dengan terlebih dahulu diuraikan konteks sejarahnya. Metode yang digunakan dalam penelitian ini adalah metode sejarah. Simpulannya adalah ketersediaan sumber bibliografis mengenai sejarah kesehatan di Indonesia yang cukup banyak itu dapat digunakan untuk merekonstruksi kondisi kesehatan di Indonesia masa kolonial. Pengetahuan sejarah kesehatan ini sangat berguna untuk melihat perubahan, kesinambungan, paralelisme, dan perbandingan masalah kesehatan di berbagai tempat pada berbagai periode.
\end{abstract}

Kata kunci: bibliografi, sejarah kedokteran, Hindia Belanda metode pengobatannya, sebab-sebab yang jadi pemicu penyakit, sarana prasarana kesehatan yang tersedia, dan sebagainya.

Sementara ini, ketersediaan sumber pustaka yang mengkaji sejarah kesehatan di Indonesia amat terbatas. Setidaknya satu buku dan satu artikel dijadikan acuan utama dalam penelitian ini. Pertama adalah buku yang ditulis oleh Denys Lombard berjudul Nusa 
Jawa Silang Budaya; Kajian Sejarah Terpadu. Bagian I: Batas-batas Pembaratan (Jakarta: Gramedia Pustaka Utama, Forum jakarta-Paris, Ecole francise d'Extreme-Orient. 2008). Pada buku ini ada sedikit tulisan, tetapi sangat informatif, mengenai masuknya ilmu kedokteran Barat (hlm. 140-143). Selain itu, ada sebuah artikel yang ditulis oleh Han Mesters berjudul "Public Health and Colonial Government in the Netherlands Indies". Artikel ini menjadi bagian dari buku yang diedit oleh Peter Boomgaard berjudul The Colonial Past; Dutch Sources on Indonesian History (Amsterdam: Royal Tropical Insitute, 1991. hlm. 41-49). Pada artikel ini diinformasikan sejumlah tulisan yang dimuat dalam berbagai terbitan pada zaman kolonial.

Masalah yang dikaji dalam penelitian ini adalah penggunaan dokumentasi dan publikasi mengenai kondisi kesehatan pada zaman kolonial baik yang dilakukan oleh pemerintah atau pun oleh lembaga-lembaga swasta. Dengan memahami perjalanan sejarah kesehatan itu banyak manfaat yang bisa diambil. Beberapa diantaranya adalah (1) Bisa diketahui hal-hal yang relatif tetap karena terjadi kesinambungan di satu sisi dan aspek-aspek yang berubah dari waktu ke waktu di sisi lain; (2) Teridentifikasinya kesejajaran ilmu kesehatan masa kini dengan masa lalu; (3) Diperoleh pengetahuan perbandingan mengenai hal-hal yang terkait dengan kesehatan di satu daerah dengan daerah lain dalam periode yang berbeda (Kuntowijoyo, 2003: xviii). Ketiga hal itu bermuara pada manfaat praktis yakni semakin meningkatkan perkembangan dan kemajuan ilmu kesehatan pada masa kini dan masa mendatang serta tidak mengulangi kesalahan atau kegagalan masa lalu. Selain itu, bagi sejarawan sendiri mengetahui sejarah kesehatan bisa mengungkap banyak hal. Misalnya, kondisi sosial, ekonomi, politik, dan budaya bisa dilacak melalui kondisi kesehatan penduduknya.

\section{METODE PENELITIAN}

Metode yang digunakan untuk penelitian ini adalah metode sejarah. Yang pertama kali dilakukan yaitu heuristik (mencari sumber). Sumber diperoleh melalui studi kepustakaan dengan fokus mencari buku-buku bibliografis. Acuan utama yang banyak digunakan dalam pengidentifikasian sumber-sumber sejarah kesehatan adalah Han Mesters (1991) dan Denys Lombard (2008). Dari buku-buku bibliografis tersebut kemudian diseleksi buku -buku atau sumber-sumber lain yang berkait dengan masalah kesehatan. Setelah sumber-sumber yang berhubungan dengan kesehatan terkumpul, kemudian dianalisis sehingga diperoleh sumber yang dianggap representatif. Yang terakhir adalah dilakukan penulisan laporan.

\section{HASIL DAN PEMBAHASAN}

Motif terbesar orang-orang Eropa umumnya dan Belanda khususnya datang ke wilayah Nusantara adalah motif ekonomi. Mereka mencari dan mengusahakan komoditas pertanian yang laku di pasar Eropa. Guna mengoptimalkan hasil-hasil produksi baik secara kuantitas maupun kualitas selain dilakukan melalui perluasan area tanam dan memperbesar modal, juga yang tidak kalah penting adalah meningkatkan jumlah tenaga kerja. Hal yang terakhir ini merupakan faktor produksi yang sangat penting saat itu karena proyekproyek kolonial lebih mengandalkan padat karya daripada padat modal.

Dalam konteks seperti itulah pemerintah kolonial menerapkan politik 
demografis yang sangat pro-natalis. Hal Orientasinya tidak hanya meningkatkan angka pertumbuhan penduduk melalui fertilitas, tapi juga menurunkan angka kematian (mortalitas). Jumlah penduduk dengan kualitas kesehatannya yang baik merupakan mesin produksi yang sangat diandalkan untuk meningkatkan produksi pertanian, perkebunan, dan pembangunan-pembangunan infrastruktur yang dibutuhkan. Di sinilah awal keterlibatan langsung dan intensif pemerintah kolonial dalam masalah kesehatan penduduk.

Sesungguhnya intervensi pihak asing terhadap persoalan kesehatan penduduk pribumi sudah dimulai sejak zaman Kompeni (VOC). Namun demikian, upaya dokter-dokter VOC hampir sia-sia karena tidak mampu memerangi penyebab yang sesungguhnya dari berbagai penyakit tropis. Mereka tak berdaya menghadapi tingkat kematian yang sampai akhir abad ke -18 tetap tinggi. Hingga abad ke-18, sejarah kedokteran tidak banyak membahas masalah pengobatan, tetapi lebih banyak menceritakan sejarah rumah sakit. Disebutkan, misalnya, di Batavia sejak tahun 1622 sudah terdapat rumah sakit; sekitar tahun 1680 dokter Ten Rhyne-yang menaruh perhatian terhadap penyakit kusta - membuka tempat perawatan penderita kusta di Pulau Purmerend (di Teluk Jakarta); kemudian dibuka rumah sakit di Banten dan Semarang, bahkan tahun 1769 dibuka rumah sakit jiwa di Jakarta. Disebutkan bahwa semua itu lebih merupakan "pengurungan" daripada perawatan yang dari sudut mentalitas merupakan gagasan memisahkan perderita dari masyarakat umum, yang dampak terapisnya hampir tidak ada (Lombard, 2008: 140-141).

Obat-obatan tardisional yang biasa digunakan oleh penduduk setempat ternyata diadopsi oleh dokter-dokter
VOC untuk digunakan dalam pengobatan. Mereka bahkan berupaya mengidentifikasi dan mendokumentasikannya. Hal tersebut disebutkan dalam karya Jacob de Bondt - dokter pribadi Jan Pieter zoon Coen - yang berjudul De Medicina Indorum. Selain itu, ada karya lain mengenai ilmu pengobatan orang pribumi yang ditulis oleh Hermann Nikolaus Grimm. Ia pernah tinggal di Batavia sejak tahun 1665 hingga 1680. Ia menulis buku berjudul Pharmacopoeia Indica, in qua continentur medicamenta, in compendio medico allegata, Quae Ex simplicubus in India crescentibus composita et ad Indorum morbos directa sunt. Fideliter veris Artis Medica perscrutatoribus annotata (Ausburg, 1684). Buku ini tidak hanya membahas tumbuhtumbuhan yang berkhasiat tapi juga bahan obat-obatan yang berasal dari hewan. Pada tahun 1746, di Batavia terbit juga sebuah buku yang berisi katalogus obat-obatan tradisional yang digunakan di Hindia Belanda. Buku tersebut berjudul Bataviasche Apotheek (Lombard, 2008: 141).

Revolusi dalam dunia kesehatan di Hindia Belanda terjadi melalui tiga hal, yaitu diperkenalkannya vaksin, kina, dan ilmu kedokteran kolonial. Mengenai vaksin, sesungguhnya sudah disosialisasikan pada tahun 1779 melalui pamflet yang disusun oleh $\mathrm{W}$. van Hogendorp yang menganjurkan vaksinasi. Bunyi pamflet itu adalah: "Sophronisba of de gelukkige moeder, door de inentinge van haare dochters" (Sofronisba, ibu yang berbahagia karena telah mengimunisasi anak-anak perempuannya). Kemudian pada tahun 1782, Verhandelingen dari Bataviasch Genootschap menerbitkan artikel-artikel ilmiah mengenai masalah vaksin (Lombard, 2008: 143). Artikel-artikel itu adalah (1) J. van der Steege, "Nader Berigt nopens den aard der kinderziekte te Batavia; in hoever men met de 
inenting gevorderd is en wat daarbij is waargenomen", VBG, I, 1779; (2) L. Bicker \& P.M. van Nielen, "Omtrent de inenting der kinderziekte in de Oostersche volkplantingen", VBG, IV, 1782. (Lombard, 2008: 280).

Langkah konkret gerakan vaksinasi baru terjadi pada tahun 1804. Pada tahun tersebut dilakukan "import" pertama vaksin melalui pengiriman dokter bedah umum bernama Gauffre ke Mauritus bersama sepuluh anak berusia 10 12 tahun untuk divaksinasi. Anak-anak tersebut kemudian dibawa pulang kembali sebagai "vaksin hidup". Selanjutnya vaksinasi sistematis dilakukan di Batavia dan di bandar-bandar pesisir sehingga penderita cacar menurun drastis. Dibangunnya Jalan Raya Daendels dapat memperluas jangkauan gerakan vaksinasi sampai ke desa-desa di Pulau Jawa. Kesulitan mobilitas "vaksin hidup" pun kemudian terpecahkan dengan digunakannya tabung "termometris" sebagai cikal bakal ampul di zaman sekarang. Tabung termometris pertama diimport dari London tahun 1819. Di Jawa vaksin diproduksi dengan mengimunisasi sapi dan kerbau. Tempat pembiakan vaksin yang pertama secara resmi didirikan tahun 1879. Dalam lima dekade terakhir abad ke-19 jumlah penduduk Pulau Jawa yang telah divaksin cukup banyak. Misalnya, pada tahun 1860 sebanyak 690.819 dan 1875 sebanyak 930.853 orang (Lombard, 2008: 142).

Antisipasi terhadap berjangkitnya wabah penyakit (cacar, malaria, tipus) kegiatan vaksinasi ditingkatkan (Owen, 1987: 50 - 65). Sebagai misal, gerakan vaksinasi di Keresidenan Priangan pertama kali dilakukan oleh dr. Andries van de Wilde. Sepanjang abad ke-19 jumlah penduduk Priangan yang divaksin terus meningkat. Bila pada dekade pertama abad ke-19 hanya ribuan, pada dekade ketujuh meningkat menjadi 50 ribuan penduduk divaksinasi. Pemerintah membentuk lembaga vaksinasi dan menambah jumlah vaksinator (mantri cacar) sehingga kegiatan vaksinasi berlangsung efektif. Wilayah tiap kabupaten dibagi menjadi dua atau lebih distrik vaksinasi. Kebijakan pemerintah dalam kesehatan, khususnya vaksin, berpengaruh besar terhadap menurunnya angka kematian pada satu sisi dan peningkatan jumlah penduduk pada sisi lain.

Selain vaksin, hal penting dalam gerakan kesehatan di Hindi Belanda adalah diperkenalkannya kina. Demam malaria merupakan penyakit tropis yang menjadi salah satu penyebab utama kematian. Kina digunakan oleh Belanda di Batavia sejak akhir abad ke18. Awalnya, kulit kayu kina didatangkan dari Amerika ke Belanda, selanjutnya, pada tahun 1854 pohon kina dibawa oleh orang Belanda bernama Hasskarl ke Hindia Belanda. Pembangunan perkebunan kina pertama kali dilakukan di daerah Pangalengan (Keresidenan Priangan) di bawah pengawasan F.W. Junghuhn (Lombard, 2008: 143).

Pada abad ke-19 Keresidenan Priangan merupakan pemasok terbesar kebutuhan kina dunia. Tanaman kina tumbuh di tanah yang punya ketinggian lebih dari 1.200 meter di atas permukaan laut. Di Keresidenan Priangan terdapat sepuluh perkebunan kina yang terletak di kaki gunung. Kesepuluh perkebunan itu adalah Cibodas di Gunung Gede, Lembang di Gunung Tangkubanperahu, Nagrak di Gunung Tangkubanperahu, Cibitung di Gunung Wayang, Cibeureum di Gunung Malabar, Cinyiruan di Gunung Malabar, Riung Gunung di Gunung Kendeng, Kawah Ciwidey di Gunung Kendeng, Rancabolang di Gunung Patuha dan Kendeng, Talaga Patenggang di Gunung Patuha, Jampang (Koloniaal Ver- 
slag 1860 Bijlage X). Pada tahun 1896 di Bandung didirikan pabrik kina. Berkat kina, kematian penduduk Jawa akibat demam malaria menurun drastis.

Terbentuknya "ilmu kedokteran kolonial" di Hindia Belanda - yang merupakan revolusi ketiga - ditunjukkan melalui (1) Penerapan fotografi di bidang kedokteran pada tahun 1842 oleh dr. J. Munnich; (2) Penggunaan ether untuk anestesi yang dilaksanakan pertama kalinya tahun 1848 di rumah sakit Surabaya; (3) Penemuan penyebab penyakit beri-beri dan adanya vitaminvitamin oleh dr. C. Eykman dan G. Grijns; (4) Berdirinya sekolah dokter pribumi pada tahun 1852; di Batavia bernama STOVIA (School Tot Opleiding van Inlandsche Artsen, Sekolah Dokter Pribumi) dan di Surabaya bernama NIAS (Nederlandsch Indisch Artsenschool, Sekolah Dokter Hindia Belanda, 1913); (5) Terbitnya majalah kedokteran pada 1853 atas prakarsa dr. W. Bosch. Majalah tersebut bernama Geneeskundig Tijdschrijf voor Nederlandsch-Indie; (6) Pembukaan rumah sakit Pasteur pada tahun 1896 yang mengkhususkan diri pada upaya memerangi rabies (Lombard, 2008: 143).

Sejak awal abad ke-20 perhatian pemerintah meningkat dalam mengontrol penyakit epidemik seperti kolera dan pes. Terutama karena pes, pemerintah kolonial mengintensifkan kegiatannya dalam bidang kesehatan umum dan higienitas. Terdapat dua perkembangan penting dalam masa perbaikan ini. Pertama, perkembangan pesat dalam ilmu medis yang dapat mencari penyebab beberapa penyakit tropis dan mengambil tindakan preventif atau melakukan tindakan-tindakan kuratif. Kedua, perubahan bertahap dalam ideologi kolonial yang dikenal dengan sebutan Politik Etis yang menghasilkan kebijakan yang lebih humanis terhadap penduduk pribumi. Ini berarti bahwa lebih banyak uang dikeluarkan oleh pemerintah colonial untuk kesejahteraan. Dalam bidang kesehatan publik hasil dari kebijakan baru ini cukup nyata.

Terdapat dua lembaga yang secara institusional diberi tanggung jawab langsung menangani masalah kesehatan. Kedua lembaga tersebut adalah Burgerlijk Geneeskundige Dienst (BGD Layanan Kesehatan Sipil) dan Dienst der Volksgezondheid (DVG - Layanan Kesehatan Publik). Lembaga-lembaga ini selain melakukan tindakan-tidakan kesehatan kuratif dan preventif, juga menerbitkan publikasi-publikasi, antara lain Mededeelingen van den Burgerlijk Geneeskundigen Dienst (Komunikasikomunikasi Layanan Pengobatan Sipil terutama dipublikasikan dalam Geneeskundig Tijdschrift voor Nederlandsch -Indie). Yang berkait dengan pelayanan pes, misalnya, terbit laporan-laporan yang dicetak sebagai lampiran pada Geneeskundig Tijdschrift voor Nederlandsch -Indie.

Beberapa dokter, seperti Dr W.A.P. Schüffner dan Dr W.A. Kuenen, dari Layanan Kesehatan Publik, melakukan penelitian tentang penyakitpenyakit tropis. Mereka bekerja sama dengan layanan kesehatan-lingkungan di perkebunan-perkebunan besar, terutama di pantai utara Sumatra. Hasil temuan penelitian mereka biasanya dipublikasikan dalam Geneeskundig Tijdschrifit voor Nederlandsch-Indie (GTNI) atau dalam buklet-buklet.

\section{Buku-buku dan Artikel-artikel Refer- ensi}

Sejumlah karya referensi penting tentang kesehatan publik, kebersihan, dan penyakit-penyakit tropis cukup tersedia. Beberapa yang sangat penting terdaftar di bawah. Artikel-artikel dan 
buku-buku itu meliputi sejumlah besar subjek seperti sejarah dan fungsi layanan-layanan kesehatan, studi kasus tentang penyakit tropis tertentu, pengaruh faktor-faktor iklim pada kesehatan di daerah tropis, dan sebagainya. Publikasi -publikasi itu adalah: (1) Control of Endemic Diseases in the Netherlands Indies, diedit oleh the Netherlands Indies Medical and Sanitary Service. Weltevreden (Landsdrukkerij) 1929; (2) Coolhaas, W. Ph., "De gezondheidszorg". dalam Insulinde, Mensch en Maatschappij. Deventer 1940; (3) Feestbundel 1936. Ter Gelegenheid van het Verschijnen van het 75 e deel van het Geneeskundig Tijdschrift voor Nederlandsch -Indie. Batavia (Kolff) 1936; (4) Flu, P.C., "Medical Science", dalam L.M.R. Rutten (ed.), Science in the Netherlands EastIndies. Amsterdam (Koninklijke Academie van Wetenschappen) 1929, hlm. 207; (5) Jonkers, A., Welvaartszorg in Indonesie. Den Haag 1948; (6) Langen, C.D. de, "Het Lichamelijk Welzijn, Gezondheidszorg, en volksvoeding", dalam W.H. van Helsdingen, H. Hoogenberk, (eds.), Daar Werd Wat Groots Verricht .... Nederlands-Indie in de XXste Eeuw. Amsterdam (Elsevier) 1941; (7) Mededeelingen van het Koloniaal Instituut in Amsterdam, Afdeeling Tropische Hygiene. Amsterdam (De Bussy); (8) Peverelli, P., De Zorg voor de Volksgezondheid in Nederlandsch-Indie. Den Haag 1942; (9) Roemer, L.S.A.M. von, Historical Sketches. An Introduction to the Fourth Congress of the Far Eastern Association of Tropical Medicine to be held at Batavia 6-13th August 1921. Batavia 1921; (10) Schoute, D., Occidental Therapeutics in the Netherlands East Indies during Three Centuries of Netherlands Settlement (1600-1900). Batavia (KoLff) 1937.

Sebuah sumber yang sangat penting adalah Het Geneeskundig Tijdschrifit voor Nederlandsch Indie (GTNI). Indeks seluruh artikel yang dipublikasi selama eksistensinya (18511942) muncul pada akhir 1991-1997. Ar- tikel-artikel dalam GTNI meliputi berbagai macam subjek pengobatan. Penyakit -penyakit tropis seperti beri-beri, tipes, pes, disentri, kusta/lepra, dan malaria dimunculkan dengan sangat baik. Subjek-subjek lain juga muncul secara teratur, seperti: luka tembak, informasi statistik tentang sebab-sebab kematian, kasus-kasus rumit yang dilihat oleh tenaga medis, dan review buku dan artikel.

\section{Publikasi-publikasi Aktual}

Selain buku dan artikel referensi yang terbit pada zaman kolonial, terdapat juga publikasi-publikasi aktual yang merupakan kajian tenteng kesehatan yang terbit tahun 1980-an. Publikasipublikasi tersebut adalah (1) Boomgaard, P., "The Welfare Services in Indonesia', Itinerario X (1986) Leiden, hlm. 57-81; (2) Heteren, G.M. van, A. de Knecht van Eckelen, M.J.D. Poulissen (eds.), Dutch Medicine in the Malay Archipelago 1816-1942. Amsterdam (Rodopi) 1989. Buku ini merupakan kumpulan paper dari kongres dalam rangka menghormati sejarawan kedokteran Prof. Dr D. de Moulin. Buku ini memuat subjeksubjek seperti kesehatan lingkungan tropis (tropical hygiene), malaria, cacar, gizi, dan pendidikan dalam pengobatan tropis; (3) Owen, Norman G. (ed.). Death and Disease in Southeast Asia. Explorations in Social, Medical and Demographic History. Singapore (Oxford University Press) 1987. Buku ini menguraikan sejarah kesehatan dan penyakit di Asia Tenggara dari sudut pandang demografi, budaya, biologi, dan politik.

\section{Publikasi BGD dan DVG}

Publikasi-publikasi dalam BGD dan DVG sering memunculkan studi kasus tentang problem kesehatan publik 
di suatu daerah di Hindia Belanda, biasanya ketika epidemik. Misalnya malaria dan pes merata melanda sejumlah daerah secara merata. Berita yang dipublikasi oleh BGD dan DVG ada yang berkala ada juga yang berupa monografi. Terbitan yang berkala adalah (1) Korte Berichten van het Hoofdbureau van den Burgerlijk Geneeskundigen Dienst. Weltevreden 1918-1921. Nomor 1-10; (2) Mededeelingen van den Dienst der Volksgezondheid in Nederlandsch-Indie. Batavia 1925-1939. Nomor 1, 1925 - jrg. 28, nomor 4; (3) Jaarverslag van den Burgerlijk Geneeskundige Dienst in NederlandschIndie, 1911-1921. Weltevreden 1919-1923.

Terbitan yang berupa monografi adalah (1) Freijtag, C.J. de, Requell voor den Geneeskundigen Dienst in Nederlandsch-Indie. Batavia 1899; (2) Gorkom. W.J. van, "De Civiel-geneeskundige Dienst op Java en Madoera". Cetak ulang dari Vragen des Tijds. Haarlem 1904; (3) Medische Propaganda door den Dienst der Volksgezondheid in Nederlands-Indie. Weltevreden 1927; (4) Peverelli, P., "De ontploofing van den Burgerlijk Geneeskundigen Dienst', dalam Feestbundel 1936. Ter Gelegenheid van het Verschijnen van het 75 e deel van het Geneeskundig Tijdschrift voor Nederiandsch-Indie. Batavia (Kolff) 1936, hlm. 178-201; (5) Rapport der Commissie tot Voorbereiding eener Reorganisatie van den Burgerlijk Geneeskundigen Dienst. Batavia 1908.

\section{Publikasi tentang Pes oleh Dienst der Pestbestrijding (Layanan Pes)}

Bibliografi penting tentang subjek ini diberikan oleh T.H. Hull, "Plague in Java", dalam N.G. Owen (ed.), Death and Disease in Southeast Asia. Singapore (Oxford University Press, 1987), hlm. 210. Pubilkasi mengenai penyakit itu adalah (1) Beknopt Overzicht Betreffende de Organisatie en Uitvoering der Pestbestrijdingsmaatregelen. Semarang 1921; (2)
Otten, L., Beschouwingen omtrent Verbreiding en Besmettingswijze van Pes, in Verband met het Waarnemen en Proefondervindelijk onderzoek op Java. Amsterdam (De Bussy) 1913. Dengan bibliografi, hlm. 87-126; (3) Otten, L., "Pestbestrijding op Java 1911-1935', dalam Feestbundel 1936. Ter Gelegenheid van het Verschijnen van het 75 e deel van het GTNI. Batavia (Kolff) 1936, hlm. 84-108; (4) Otten, L., "De Pest op Java, 19111923“, Mededeelingen van de Dienst der Volksgezondheid in Nederlandsch-Indie nomor 13, hlm. 119-263; (5) "Verslag betreffende de Pestbestrijding op Java over het Jaar 1939“, Mededeelingen van den Dienst der Volkgezondheid in NederlandschIndie nomor 30,1941, hlm. 158-214.

\section{Publikasi oleh Layanan Kesehatan Militer}

Perawatan kesehatan awalnya merupakan sebuah hak istimewa yang eksklusif bagi orang-orang Eropa di Hindia Belanda. Pada pertengahan abad ke-19 Dr. Willem Bosch mencoba menyediakan juga perawatan kesehatan bagi penduduk pribumi. Sejak 1827 hingga 1911, ilmu kedokteran secara luas berada di tangan militer, dan semua dokter adalah dokter militer. Publikasi-publikasi itu adalah (1) Kerkhof, A.H.M., "De Organisatie van de Militaire en Burgerlijke Geneeskundige Dienst in de Negentiende Eeuw", dalam G.M. van Heteren et al. (eds.), Nederlandse Geneeskunde in de Indische Archipel 1816-1942. Amsterdam (Rodopi), 1989, hlm. 7; (2) Ludeking, E.W.A., Recueil voor den Militair Geneeskundigen Dienst in Nederlandsch-Indie. Batavia (Van Dorp), 1871; (3) Regelement voor de Militaire Ziekeninrichtingen in Nederlairdsch-Indie. Cetak ulang, 1920; (4) Schouten, D., De Geneeskunde in Nederlandscit-Indiie gedurende de Negentiende Eeuw. Batavia (Kolff), 1934; (5) Tissot van Patot, PN, 
Vergelijkend Onderzoek van de Gezondheidstoestand in het Nederlandsch-Indisch Leger over 1930 en de Laatste 10 tot 25 Voorafgaande Jaren. Batavia (Kolff), 1932; (6) Veer, W. van der, "De Militair Geneeskundige Dienst 1911-1935", dalam Feestbundel 1936. Ter Gelegenheid van het Verschijnen van het 75e Deel van het GTNI. Batavia (Kolff), 1936, hlm. 202234.

\section{Publikasi tentang Layanan Kesehatan Publik di Kota-kota Besar}

Menyadari bahwa bahaya penyakit-penyakit menular sangat tinggi di kota-kota besar daripada di daerah luar kota, pemerintah Belanda mengambil tindakan untuk memperbaiki kebersihan lingkungan. Sejak permulaan abad ke-20 sejumlah tindakan dilakukan seperti penyediaan air bersih. Publikasipublikasi berkaitan dengan hal itu antara lain (1) Beknopt Overzicht van de Verrichtingen op Hygienisch Gebied in de Jaren $1910 \mathrm{t} / \mathrm{m}$ 1926. Weltevreden (Indonesische drukkerij) 1927. (Publikasi di kota Batavia); (2) De Hygiene in de Gemeente Soerabaia, met bijdragen van J. van Kleef etc. Soerabaia (Van Dorp), hlm. 191-197; (3) "Pokken Epidemie in Gemeente Bandoeng 1946, 1947, 1948", dalam Verslagen Gezondheidsdienst Bandoeng. 1949 dengan indeks.

\section{Publikasi tentang Higienis dan Pengo- batan di Perkebunan}

Sejak 1870 inisiatif swasta meningkat tajam, terutama di Sumatera, di mana di situ terdapat perkebunanperkebunan besar dengan tenaga buruh yang banyak. Kebanyakan buruh adalah imigran dari berbagai negara Hindia Timur dan Cina. Mereka tidak biasa dengan kondisi kehidupan dan lingkun- gan setempat sehingga banyak jatuh korban malaria. Permulaan 1880 -KoeliOrdonnantie diterapkan dan ini merupakan langkah legislatif yang penting untuk memperbaiki kesehatan buruhburuh perkebunan. Para pengusaha harus menyediakan perumahan, makanan, dan pengobatan gratis. Publikasi mengenai hal itu adalah (1) Apituley, H.J.D., "Onderwijs in de Hygiene voor Nederlandsch-Indie, een Kort Verslag der Discussie naar Aanleiding van deze Voordracht', dalam Voordracht van de Nederlandsch-Indische Vereeniging nomor 7 (2e bundel nomor 3). Den Haag ,1914; (2) Bandoeng, Eerste Hygienische Tentoonstelling in Nederlandsch-Indie, 1927. Catalogus voor de inzending van den Dienst der Volksgezondheid. Weltevreden, 1927; (3) Gulik, P.J. van, De Medisch-hygienische Dienst der Mijnbouw Maatschappij Redjang Lebong gedurende het Tijdvak 19251929. Amsterdam, 1930. (Ph.D. thesis); (4) Hydrick, J.L. Intensief Hygiene Werk en Medisch Hygienische Propaganda van den Dienst der Volksgezondheid in Nederlandsch-Indie. Batavia, 1936; (5) Hydrick, J. L., De Afdeling Medisch Hygienische Propaganda van de Dienst der Volksgezondheid in Nederiandsch-Indie, 1922; (6) Hydrick, J.L., Intensive Rural Hygiene Work and Public Health Education of the Public Health Service of Netherlands-India. Java, Batavia (Centrum), 1937; (7) Jaarverslag van het Laboratorium voor Technische Hygiene 1935. Bandoeng, 1936; (8) Kouwenaar, W, "De organisatie van den Medischen en Hygienischen Dienst in het Cultuturgebied der Oostkust van Sumatra". Cetak ulang dari Geneeskundig Tijdschrift van Nederlandsch-Indie dl. 69, afl. 6. Weltevreden, 1929; (9) Kuenen, W.A., De Hygienische Toestanden in Deli. Semarang (Deli-plantersvereniging), 1914 (Brochure); (10) Nationaal Rapport van Nederiands-Indie; voor de Intergouvernementele Conferentie vanL in het Verre Oosten voor Landelijke Hygiene, 3-13 Augustus 1937; (11) Penris, Geneeskundige 
Venzorging van Arbeiders bij Landbouwondernemingen op Java. Amsterdam, 1930. (Ph.D. thesis); (12) Songhonning, A., Iets over Hygiene i.v.m. Adat, Geloof en Bijgeloof van het Soedaneesche Volk. Bandoeng, 1927. (Publicatie van de Nederlandsche Vereniging ter Bevordering der Hygiene in Nederiands-Indie, nomor 10); (13) Schuffner, W.A.P., Voorspoed en Tegenspoed op het Gebied der Tropische Hygiene. Amsterdam, 1938; (14) Schuffner, W.A.P., Kuenen, W.A., De Gezondheidstoestand van de Arbeiders Verbonden aan de Senembah-maatschappij op Sumatra Gedurende de Jaren 1897 tot 1907. Amsterdam (De Bussy), 1910; (15) Vervoort, H., Eenige Statistische Cijfers over Ziekte- en Sterftecijfers onder de Arbeiders op de Ondernemingen op de Oost-kust van Sumatra over het Jaar 1918. Medan, 1921.

\section{Publikasi Layanan Karantina}

Kemajuan dalam bidang transportasi mendorong dilaksanakannya persetujuan internasional untuk menjaga penyebaran penyakit-penyakit epidemik ke seluruh dunia. Epidemik pes di India (1896) secara khusus menuntut bahwa disinfeksi kapal-kapal dan pengawasan kesehatan penumpang menjadi suatu kemestian. Publikasi berkait dengan hal tersebut adalah (1) Horst, M.D., Wettelijke Voorschriften omtrent Quarantaille en Bestrijding van Besmettelijk Ziektes in Nederlands-Indie tot 1 Jan. 1917. Leiden (Leidse Vereeniging ter bevordering van de studie der Tropische Geneeskunde, afd. hygiene en bacteriologie), 1917. (2) Quarantaine-en Evidemievoorschriften in Nederlands-Indie. Batavia (Uitgave van de Dienst der Volksgezondheid), 1939.

\section{Publikasi oleh Masyarakat}

Publikasi ini dilakukan oleh "de
Delische Kring" (1896). Masyarakat tanaga medis menekankan pada pengobatan masyarakat, memperhatikan gizi, kesehatan anak, higienis, dan bangunan rumah. Mereka memberi nasihat tentang masalah-masalah kesehatan masyarakat di perkebunan-perkebunan besar, terutama yang berkaitan dengan kolera. Publikasi-publikasi yang muncul adalah (1) Bulletin van den Bond van Geneesheren in Nederlandsch-Indie, nomor 62, nomor 77-326. Soerabaia, 1913-1940; (2) Driel, B.M. van, “De Sociale Geneeskunde in den Delischen Kring", dalam Feestbundel 1936. Ter Gelegenheid van het Verschijnen van het 75e Deel van het GTNI. Batavia (KoIff), 1936, hlm. 303319; (3) Feestbundei ter Herinnering Uitgegeven bij het Verschijnen van het 50e Deel van het Geneeskundig Tijdschrift voor Nederlandsch-Indie. Batavia (Javaarische boekhandel), 1911; (4) Geneeskundig Tijdschrift voor Nederiandsch-Indie. Batavia 1854-1940; (5) Herinneringsbundel ter Gelegenheid van het 25-jarig Bestaan der Vereeniging Instituut voor Tropische Geneeskunde. Leiden, 1934; (6) Loghem, J.J. van, "Wegen en Middelen tot Verbetering van de Volksgezondheid in Onze Kolonien", dalam Verslag van de Algemeene Vergadering van 8-11-1915 van het Indisch Genootschap. Den Haag, 1915; (7) Semarang, Eerste Congres van de Vereniging van Indische Geneeskundigen. Batavia, 1939; (8) Vereniging tot Bevordering der Geneeskundige Wetenschappen in Indonesie. Medisch Maandblad nomor 23-29, deel 2, nomor 1, deel 3, nomor 12. Djakarta, 1948-1950; (9) Waart, A. de, Beschouwingen naar Aaleiding van eene Medische Studiereis in 0ost-Azie. Weltevreden (KoIff), 1923. (Publicatie van de Vereniging voor Studie van Koloniaal Maatschappeiijke Vraagstukken); (10) Weltevreden, Vierde Congres der Far East Association of Tropical Medicine (FEATM). 2 Vols. 1921; (11) Wirickel, C.W.F., De Nederlandse Vereniging voor 
Tropische Geneeskunde, 1907-1957. Amsterdam 1957.

\section{Publikasi yang Berkaitan dengan Pen- didikan dan Penelitian}

Pada 1876 sekolah kesehatan bagi dokter pribumi dibuka di Jakarta. Pada 1913 sekolah yang sama dibangun di Surabaya. Namun demikian, sebelum 1927, mahasiswa pribumi harus berangkat ke Negeri Belanda untuk mendapatkan gelar akademik dokter. Setelah reorganisasi sekolah kedokteran di Batavia pada 1927, pendidikan kedokteran di Batavia disamakan dengan sekolahsekolah kedokteran di Negeri Belanda. Penelitian ilmiah kedokteran dilakukan di laboratorium-laboratorium di perbagai pulau. Publikasi-publikasi yang terbit adalah (1) Heteren, G.M. van, "De Tropencursus te Amsterdam: een Geval van Monopolisering?", dalam G.M. van Heteren et al. (eds.), Nederlandse Geneeskunde in de Indische Archipel 18161942. Amsterdam (Rodopi) 1989, hlm. 33 -52; (2) Kan, P. Th., Het Tropisch Geneeskundig Onderwijs in Nederland in Verband met de Opvattingen van den Minister van Kolonien daar over. Z. pl. en Jaar; (3) Kouwenaar, W., "Het aandeel van Nederland in de Vooruitgang der Geneeskundige Wetenschap van 19001950". Nederlands Tijdschrifit voor Geneeskunde, 1951; (4) Kuenen, W.A., De Ontwikkeling der Tropische Ziekteleer. Amsterdam 1918; (5) Kuenen, W.A., Het Tropisch Geneeskundig Onderwijs in Nederland in Gevaar. Amsterdam 1917; (6) Regelement Betreffende de Bevoegdheden en Verplichtingen van de Dokters Djawa Vastgesteld bij het Besluit van de Directeur van Orde, Eeredienst en Nijverheid van 2 Jan. 1902, nomor 32. Batavia, 1902; (7) Schuffner, W.A.P., Een Stukje Geschiedenis van Deli, een Klein Blaadje aart de Reuzenboom der Medische Wetenschap. Cetak ulang dari Mededeeling van het Pathologisch Laboratorium te Medan. 1931; (8) Si Benteng, Opleiding van Geneeskundigen voor Nederlandsch-Indie. Leiden (Blankenberg), 1889; (9) Verslag over de Onderzoekingen Verricht in het Laboratorium voor Pathologische Anatomie en Bacteriologie te Weltevreden gedurende het Jaar 1891, 1892 en 1893; (10) Waart, A. de, "Het Indisch Geneeskundig Onderwijs in de Laatste Jaren", dalam Feestbundel 1936. Ter Gelegenheid van het 75e Deel van het GTNI. Batavia (Kolff), 1936, pp. 246-257.

\section{Publikasi mengenai Penyakit Tropis Lainnya}

Publikasi berkenaan dengan penyakit-penyakit tropis lainnya adalah (1) "Bestrijding van de Volksziekten in Nederiandsch-Indie". Cetak ulang dari Mededeelingen der Regeering omtrent enkele onderwerpen van algenmeen belang. Weltevreden, 1928; (2) Brand. W., "Sterfte in Batavia, 1929-1931". Cetak ulang dari Geneeskundig Tijdschrift van Nederlandsch-Indie, maart 1940; (3) Doorenbos, W.B., Speciessaneering en, Afleiding op Dieren, als Bestrijdingsmaatregelen tegen Malaria in de Tropen. Leiden 1925. (Ph.D. thesis); (4) Jeronymus, Eene Epidemie op Java en de Cholera in Nederland. Amsterdam (Van Kampen), 1849; (5) Kiewit de Jonge, G.W., Voordrachten over de Tropische Ziekten van den OostIndischen Archipel. Deel 1: Malaria, Zwart Waterkoorts. Batavia, 1908; (6) Kuipers, L, Mathematisch-statistisch Onderzoek van Waarnemingen over Anopheles in Nederland en op Java. Delft, 1937. (Ph.D. thesis); (7) Malaria en de Grote Cultures. Bandoeng (Uitgave van de Bandoengse kinine-fabriek), 1927; (8) Schwellenerebel, N.H., De Vooruitgang der Malariabestrijding in Nederlandsch-Indie. Amsterdam, 1920; (10) Semmelink, J., Geschiedenis der Cholera in Oost-Indie voor 1817. Utrecht, 1885; (11) Verdoorn, J.A., Verloskundige 
Hulp voor de Bevolking van NederiandsIndie: een Sociaal-medische Studie. Den Haag, 1941. (Ph.D. thesis, Leiden).

\section{Publikasi Lainnya}

Publikasi-publikasi lain yang berhubungan dengan kesehatan adalah (1) Burg, C.L. van der, De Geneesheer in Nederlandsch-Indie. Batavia 1882-1887. Deel 2. Batavia 1887; (2) Engelhart, C.F., Het Onderzoek naar de Geestesgesteldheid m.b.v. Platen Toegepast bij den Javaan: Mededeling uit het Doorgangshuis voor Inlandse Krankzinnigen te Soerakarta. Leiden, 1923. (Ph.D. thesis); (3) Feestbundel Uitgegeven ter Gelegenheid van de Opening van het Nieuwe Geneeskundige Laboratorium: te Salemba. Weltevreden, Batavia, 1917; (4) Geneeskundig Jaarboekje voor Nederlandsch -Indie. Weltevreden (Kolff), 1930; (5) Later, J.F.H.A., "Om dit Land Gezond te Krijgen. Een Beschouwing over den Gezondheidstoestand van NederlandschIndie vooral van Java, en de wijze waarop Verbetering daarin kan worden Aangebracht". Cetak ulang dari De Locomotief. Semarang 1915; (6) Lochem, J.J. van, Winckel, C.W.F., Kouwenaar, W., "Indie voor den Oorlog, Artikelen over de Volksgezondheid in Indie". 1948. Cetak ulang dari Nederlands Tijdschrift voor Geneeskunde, jrg. 92, 1948; (7) Lustrumnummer van het NIAS (NederlandsIndische Artsen School)-orgaan, 1913-1928. Soerabaya 1928; (8) Swellengrebel, N.H., De Vooruitzichten der Malariabestrijding in Nederlandsch-Indie. Amsterdam, 1920.

\section{SIMPULAN}

Kehadiran bangsa asing di Nusantara membawa pengaruh dalam dunia kesehatan, khususnya dalam dunia pengobatan. Periode VOC merupakan masa transisi, pada satu pihak sistem pengobatan tradisional masih berlaku, di pi- hak lain lembaga-lembaga kesehatan modern sudah mulai dibangun. Intervensi pemerintah kolonial yang semakin intensif dan sistematis terjadi pada awal abad ke-19 sejalan dengan makin intensifnya ekonomi perkebunan. Ekonomi perkebunan memerlukan jumlah tenaga kerja yang banyak, kuat, dan sehat. Dalam konteks inilah pemerintah kolonial berkepentingan dengan kesehatan penduduk.

Sistem pengobatan modern, ditandai dengan dibangunnya rumahrumah sakit, dibentuknya laboratorium dan pusat-pusat penelitian, lembagalembaga pendidikan kesehatan menunjukkan makin seriusnya upaya pemerintah kolonial dalam bidang kesehatan penduduk; lebih-lebih setelah Politik Etis diberlakukan. Semua upaya kesehatan adalah munculnya aneka ragam publikasi berupa buku, majalah, artikel yang mengangkat tema-tema kesehatan. Publikasi-publikasi ini sangat berguna ketika para peneliti sekarang ini berminat menapaki jejak-jejak perjalan dunia kesehatan di Nusantara masa lampau.

\section{DAFTAR PUSTAKA}

Boomgaard, Peter (ed.). 1991. The Colonial Past; Dutch Sources on Indonesian History. Amsterdam: Royal Tropical Insitute.

van Dorn, Marlene. 1979. Bouwstoffen voor de social-economische geschiedenis van Indonesie van ca. 1800 tot 1940; een beschrijuende bibliografie, deel 2. Amsterdam: Koninlijk Instituut voor de Tropen.

International Council on Archives. 1989. Guide to the Sources of Asian History. Jakarta: Arsip Nasional.

Jaquet, Frist G.P. 1983. Sources of the History of Asia and Oceania in the Netherlands. Part II: Sources 1796-1949. Munchen: K.G. Saur.

Koloniaal Verslag. 1860. Bijlage X.

Lombard, Denys. 2008. Nusa Jawa Silang Budaya; Kajian Sejarah Terpadu. Bagian I: 
Bibliografi Sejarah Kesehatan pada Masa Pemerintahan Hindia Belanda - Mumuh Muhsin

Batas-batas Pembaratan. Jakarta: Gramedia Pustaka Utama, Forum jakarta-Paris, Ecole francise d'ExtremeOrient.

Mesters, Han. 1991. “Public Health and Co- lonial Government in the Netherlands Indies", dalam Peter Boomgaard (ed.). The Colonial Past; Dutch Sources on Indonesian History. Amsterdam: Royal Tropical Insitute; pp. 41-49. 